\title{
The Quaternary groundwater as the low temperature energy source for heat pumps in Małopolska Province
}

\author{
Ewa Kmiecik $^{1, *}$, Barbara Tomaszewska ${ }^{1}$, and Justyna Mazurkiewicz ${ }^{1}$ \\ ${ }^{1}$ AGH University of Science and Technology, Faculty of Geology, Geophysics and Environmental \\ Protection, al. Mickiewicza 30, 30-059 Kraków, Poland
}

\begin{abstract}
The paper presents the assessment of using Quaternary groundwater as the low-temperature energy source for heat pumps in the Małopolska Province. The analysis demonstrates that the Małopolska region has potential to use Quaternary groundwater in low-temperature systems both in terms of potential well flow rates and water temperature. Water as a heat source must also meet the relevant requirements in terms of the physical and chemical parameters indicated by manufacturers of heat pumps as important for the proper operation of installations. The data for this study were obtained from the Polish Hydrogeological Survey (the PHS is carried out by the Polish Geological Institute - National Research Institute). In some cases, physical and chemical properties of water do not meet the requirements indicated by heat pump manufacturers. These requirements may be met by using recycled water or another medium whose parameters do not affect the life of the installation.
\end{abstract}

\section{Introduction}

In low-temperature geothermal installations, groundwater can be used in open systems, in which energy is transported by water (double-well and single-well installations) [1, 2]. Groundwater can be used in water/water systems if certain basic conditions are met: sufficient well flow rate (approx. $1.2-1.5 \mathrm{~m}^{3} / \mathrm{h}$ per each $5 \mathrm{~kW}$ of heating power), water temperature in the range from +4 to $+20^{\circ} \mathrm{C}$ and suitable physical and chemical composition of water [2].

If the mineral content of water is not excessively high and it is not aggressive towards the materials used in the installation, and the values of selected indicators do not exceed the limits set by the manufacturer in question, groundwater can be used as a source of lowtemperature heat and pumped directly into the heat pump evaporator [1-5]. Unfortunately, in many cases these requirements cannot be met; in such cases, an intermediate circuit heat exchanger must be used at the low-temperature heat source side, before the heat pump [1-4, 6-8]; this heat exchanger should be individually tailored to each system.

\footnotetext{
*Corresponding author: ewa.kmiecik@agh.edu.pl
} 
In this paper potential opportunities for using groundwater from Quaternary formations in double-well and single-well low-temperature systems assisted by water/water heat pumps in the Małopolska Province are analysed. Its temperature and well flow rates enable such groundwater to be used as the low-temperature heat source $[2,9,10]$.

The paper focuses on the analysis of physical and chemical properties of the waters tested with respect to the requirements indicated by the three leading heat pump manufacturers (Ochsner Wärmepumpen GmbH, Viessmann Ltd. and Dimplex Ltd.). To this purpose, data were obtained from the Central Hydrogeological Database (so-called Bank Hydro). Those were physical and chemical analyses from the years 2000-2013 for 838 wells that were used for extracting water from Quaternary formations; they concerned selected physical and chemical indicators: $\mathrm{pH}$, electrical conductivity (EC) and concentrations of chlorides $\left(\mathrm{Cl}^{-}\right)$, sulphates $\left(\mathrm{SO}_{4}{ }^{2-}\right)$, nitrates $\left(\mathrm{NO}_{3}^{-}\right)$, bicarbonates $\left(\mathrm{HCO}_{3}{ }^{-}\right)$, iron $(\mathrm{Fe})$, manganese $(\mathrm{Mn})$, ammonium $\left(\mathrm{NH}_{4}\right)$, oxygen $\left(\mathrm{O}_{2}\right)$, free (aggressive) carbonic acid $\left(\mathrm{CO}_{2}\right.$ agg.) and aluminium $(\mathrm{Al})$.

\section{Study area characteristics}

The Małopolska Province is situated in the south of Poland. It has an area of $15,183 \mathrm{~km}^{2}$ $(1,518,279$ hectares), which corresponds to $4.8 \%$ of total country area [11]. The area in question includes several units that differ in terms of their geological structures. Its southernmost part are the Inner and Outer Carpathians, which include Paleogene formations, Cretaceous flysch and Oligocene formations. The middle part is the Miocene Carpathian Foredeep, while in the northern and western parts Mesozoic structures are present: the Jurassic and Triassic Silesian-Cracow Monocline, the Cretaceous Miechów Basin and the Paleozoic structures of the Upper Silesian Foredeep [12-14]. Carpathians and their foreland (the Carpathian Foredeep) cover the overwhelming majority of the area (ca. 80\%) [12, 15, $16]$.

The amount of groundwater resources that have been developed and can be extracted in the Małopolska Province has been estimated at 74,697.10 $\mathrm{m}^{3} / \mathrm{h}$ (as at 31 December 2015), of which $40,893.79 \mathrm{~m}^{3} / \mathrm{h}(54.75 \%$ of resources $)$ is located in Quaternary formations, $9,220.03 \mathrm{~m}^{3} / \mathrm{h}(12.34 \%)$ in Tertiary formations, $12,974.03 \mathrm{~m}^{3} / \mathrm{h}(17.37 \%)$ in Cretaceous formations and $11,609.25 \mathrm{~m}^{3} / \mathrm{h}(15.54 \%)$ in older formations [17]. As concerns their hydrochemical properties, waters from Quaternary formations usually contain multiple mineral ions. Bicarbonates, sulphates, calcium, magnesium and sodium dominate. Most Quaternary groundwater reservoirs do not have insulating covers in top aquifer layers, which facilitates the penetration of pollutants from the surface [18-19].

\section{Research methodology}

In order to evaluate the possibility of using groundwater from Quaternary formations in low-temperature geothermal systems in the Małopolska Province, data from 838 wells present in the Central Hydrogeological Database were analysed; the relevant physical and chemical analyses of water had been conducted between 2000 and 2013. Locations of these wells are shown in Fig. 1.

Tests of chemical composition of water in Quaternary wells in the years 2000-2013 were conducted by different laboratories with different methodologies and with different limits of quantification, which may be reflected in a greater variability of the parameters analysed. Unfortunately, no data on the testing methodology used are included in the Central Hydrogeological Database. Table 1 shows minimum and maximum values of the parameters analysed, which are compared to the limits indicated by three leading 
manufacturers of heat pumps in Poland - Ochsner Wärmepumpen GmbH, Viessmann Ltd. and Dimplex Ltd., which offer also water/water pumps.

Table 1. Characteristics of physical and chemical parameters of groundwater (Quaternary formations, Małopolska Province, based on the Central Hydrogeological Database) (n.d. - not determined, "+" - the material is usually resistant, " 0 " - may lead to corrosion where the value of most factors is " 0 ", "--" - use is not recommended) [10].

\begin{tabular}{|c|c|c|c|c|c|c|c|c|c|c|c|c|}
\hline \multirow{3}{*}{ Parameter } & \multirow{3}{*}{ Unit } & \multirow{2}{*}{\multicolumn{2}{|c|}{$\begin{array}{l}\text { Chemical } \\
\text { composition }\end{array}$}} & \multicolumn{9}{|c|}{ Limits for physical and chemical parameters according to } \\
\hline & & & & \multicolumn{3}{|c|}{$\begin{array}{c}\text { Ochsner Wärmepumpen } \\
\text { GmbH }\end{array}$} & \multicolumn{3}{|c|}{ Viessmann Ltd. } & \multicolumn{3}{|c|}{ Dimplex Ltd. } \\
\hline & & $\min$ & $\max$ & value & copper & $\begin{array}{c}\text { stainless } \\
\text { steel }\end{array}$ & value & copper & $\begin{array}{c}\text { stainless } \\
\text { steel }\end{array}$ & value & copper & $\begin{array}{l}\text { stainless } \\
\text { steel }\end{array}$ \\
\hline $\mathrm{pH}$ & - & 3.6 & 13.1 & $\begin{array}{l}<6 \\
6-8 \\
>8\end{array}$ & $\begin{array}{l}0 \\
+ \\
- \\
\end{array}$ & $\begin{array}{l}0 \\
+ \\
0 \\
\end{array}$ & $\begin{array}{c}<7.5 \\
7.5-9 \\
>9\end{array}$ & $\begin{array}{l}0 \\
+ \\
0\end{array}$ & $\begin{array}{l}0 \\
+ \\
+ \\
\end{array}$ & $\begin{array}{c}<7.5 \\
7.5-9 \\
>9\end{array}$ & $\begin{array}{l}0 \\
+ \\
0\end{array}$ & $\begin{array}{l}0 \\
+ \\
+ \\
\end{array}$ \\
\hline $\mathrm{Cl}^{-}$ & $\mathrm{mg} / \mathrm{dm}^{3}$ & 0.95 & $2,739.2$ & $\begin{array}{c}<100 \\
100-200 \\
>200\end{array}$ & $\begin{array}{l}+ \\
0 \\
-\end{array}$ & $\begin{array}{l}+ \\
+ \\
-\end{array}$ & $\begin{array}{l}<300 \\
>300\end{array}$ & $\begin{array}{l}+ \\
0\end{array}$ & $\begin{array}{l}+ \\
0\end{array}$ & $\begin{array}{l}<300 \\
>300\end{array}$ & $\begin{array}{l}+ \\
0\end{array}$ & $\begin{array}{l}+ \\
0\end{array}$ \\
\hline $\mathrm{NO}_{3}^{-}$ & $\mathrm{mg} / \mathrm{dm}^{3}$ & $<\mathrm{DL}$ & 551.7 & n.d. & n.d. & n.d. & $\begin{array}{l}<100 \\
>100\end{array}$ & $\begin{array}{l}+ \\
0\end{array}$ & $\begin{array}{l}+ \\
+\end{array}$ & $\begin{array}{l}<100 \\
>100\end{array}$ & $\begin{array}{l}+ \\
0\end{array}$ & $\begin{array}{l}+ \\
+\end{array}$ \\
\hline $\mathrm{SO}_{4}^{2-}$ & $\mathrm{mg} / \mathrm{dm}^{3}$ & $<\mathrm{DL}$ & 1,967 & $\begin{array}{c}<50 \\
50-100 \\
>100\end{array}$ & $\begin{array}{l}+ \\
0 \\
-\end{array}$ & $\begin{array}{l}+ \\
+ \\
0\end{array}$ & $\begin{array}{c}<70 \\
70- \\
300 \\
>300 \\
\end{array}$ & $\begin{array}{l}+ \\
0 \\
-\end{array}$ & $\begin{array}{l}+ \\
+ \\
0\end{array}$ & $\begin{array}{c}<70 \\
70-300 \\
>300\end{array}$ & $\begin{array}{l}+ \\
0 \\
-\end{array}$ & $\begin{array}{l}+ \\
+ \\
0\end{array}$ \\
\hline $\mathrm{CO}_{2}$ agg. & $\mathrm{mg} / \mathrm{dm}^{3}$ & 0.2 & 70 & $\begin{array}{c}<5 \\
5-20 \\
>20\end{array}$ & $\begin{array}{l}+ \\
0 \\
-\end{array}$ & $\begin{array}{l}+ \\
+ \\
0\end{array}$ & $\begin{array}{c}<5 \\
5-20 \\
>20\end{array}$ & $\begin{array}{l}+ \\
0 \\
-\end{array}$ & $\begin{array}{l}+ \\
+ \\
0\end{array}$ & $\begin{array}{c}<5 \\
5-20 \\
>20\end{array}$ & $\begin{array}{l}+ \\
0 \\
-\end{array}$ & $\begin{array}{l}+ \\
+ \\
0\end{array}$ \\
\hline $\mathrm{Fe}$ & $\mathrm{mg} / \mathrm{dm}^{3}$ & $<\mathrm{DL}$ & 48.39 & $\begin{array}{c}>0.2 \\
(\text { Fe with } \\
\text { Mn) }\end{array}$ & - & - & $\begin{array}{l}<0.2 \\
>0.2\end{array}$ & $\begin{array}{l}+ \\
0\end{array}$ & + & $\begin{array}{l}<0.2 \\
>0.2\end{array}$ & $\begin{array}{l}+ \\
0\end{array}$ & $\begin{array}{l}+ \\
0\end{array}$ \\
\hline $\mathrm{Mn}$ & $\mathrm{mg} / \mathrm{dm}^{3}$ & $<\mathrm{DL}$ & 62.3 & $>0.05$ & - & - & $\begin{array}{l}<0.1 \\
>0.1\end{array}$ & $\begin{array}{l}+ \\
0\end{array}$ & $\begin{array}{l}+ \\
0\end{array}$ & $\begin{array}{l}<0.1 \\
>0.1\end{array}$ & $\begin{array}{l}+ \\
0\end{array}$ & $\begin{array}{l}+ \\
0\end{array}$ \\
\hline $\mathrm{O}_{2}$ & $\mathrm{mg} / \mathrm{dm}^{3}$ & 0.4 & 10.2 & $\begin{array}{l}<1 \\
1-8 \\
>8\end{array}$ & $\begin{array}{l}+ \\
0 \\
-\end{array}$ & $\begin{array}{l}+ \\
+ \\
+\end{array}$ & $\begin{array}{l}<0.2 \\
>0.2\end{array}$ & $\begin{array}{l}+ \\
0\end{array}$ & $\begin{array}{l}+ \\
+\end{array}$ & $\begin{array}{l}<2 \\
>2\end{array}$ & $\begin{array}{l}+ \\
0\end{array}$ & $\begin{array}{l}+ \\
+\end{array}$ \\
\hline $\mathrm{EC}$ & $\mu \mathrm{S} / \mathrm{cm}$ & 8.4 & $12,915.5$ & $>600$ & - & + & $\begin{array}{c}<10 \\
10- \\
500 \\
>500\end{array}$ & $\begin{array}{l}0 \\
+ \\
-\end{array}$ & $\begin{array}{l}0 \\
+ \\
0\end{array}$ & $\begin{array}{c}<10 \\
10-500 \\
>500\end{array}$ & $\begin{array}{l}0 \\
+ \\
-\end{array}$ & $\begin{array}{l}0 \\
+ \\
0\end{array}$ \\
\hline $\mathrm{HCO}_{3}^{-}$ & $\mathrm{mg} / \mathrm{dm}^{3}$ & 68.5 & 774 & n.d. & n.d. & n.d. & $\begin{array}{c}<70 \\
70- \\
300 \\
>300\end{array}$ & $\begin{array}{l}0 \\
+ \\
0\end{array}$ & $\begin{array}{l}+ \\
+ \\
0\end{array}$ & $\begin{array}{c}<70 \\
70-300 \\
>300\end{array}$ & $\begin{array}{l}0 \\
+ \\
0\end{array}$ & $\begin{array}{l}+ \\
+ \\
0\end{array}$ \\
\hline $\mathrm{NH}_{4}$ & $\mathrm{mg} / \mathrm{dm}^{3}$ & $<\mathrm{DL}$ & 16.2 & $\begin{array}{c}<2 \\
2-20 \\
>20 \\
\end{array}$ & $\begin{array}{l}+ \\
0 \\
-\end{array}$ & $\begin{array}{l}+ \\
+ \\
+\end{array}$ & $\begin{array}{c}<2 \\
2-20 \\
>20 \\
\end{array}$ & $\begin{array}{l}+ \\
0 \\
- \\
\end{array}$ & $\begin{array}{l}+ \\
+ \\
0 \\
\end{array}$ & $\begin{array}{c}<2 \\
2-20 \\
>20 \\
\end{array}$ & $\begin{array}{l}+ \\
0 \\
- \\
\end{array}$ & $\begin{array}{l}+ \\
+ \\
0 \\
\end{array}$ \\
\hline $\mathrm{Al}$ & $\mathrm{mg} / \mathrm{dm}^{3}$ & $<\mathrm{DL}$ & 0.26 & n.d. & n.d. & n.d. & $\begin{array}{l}<0.2 \\
>0.2 \\
\end{array}$ & $\begin{array}{l}+ \\
0\end{array}$ & $\begin{array}{l}+ \\
+ \\
+\end{array}$ & $\begin{array}{l}<0.2 \\
>0.2\end{array}$ & n.d. & n.d. \\
\hline
\end{tabular}

\section{Data analysis}

The largest number of facilities that extract water from Quaternary formations and that are included in the Central Hydrogeological Database are located in the Outer Carpathians and within the Carpathian Foredeep, especially within large urban areas such as Kraków, Nowy Sącz, Oświęcim and Nowy Targ (Fig. 1). The distribution of these facilities in Małopolska is not uniform, but this does not mean that there are no wells used to extract water from Quaternary formations in other areas. There may be wells with depths less than $30 \mathrm{~m}$, which pursuant to applicable laws do not require hydrogeological documentation to be compiled after geological work has been conducted and thus are not included in the Central Hydrogeological Database. 
a)

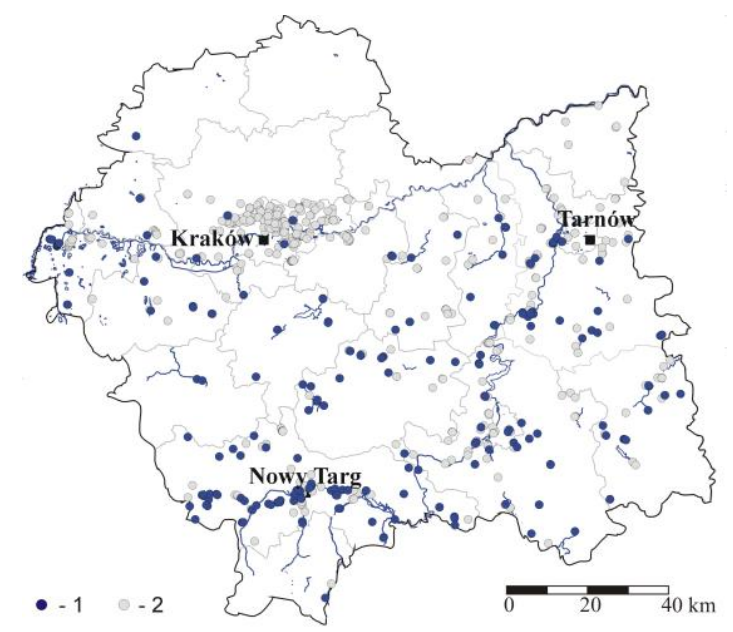

b)

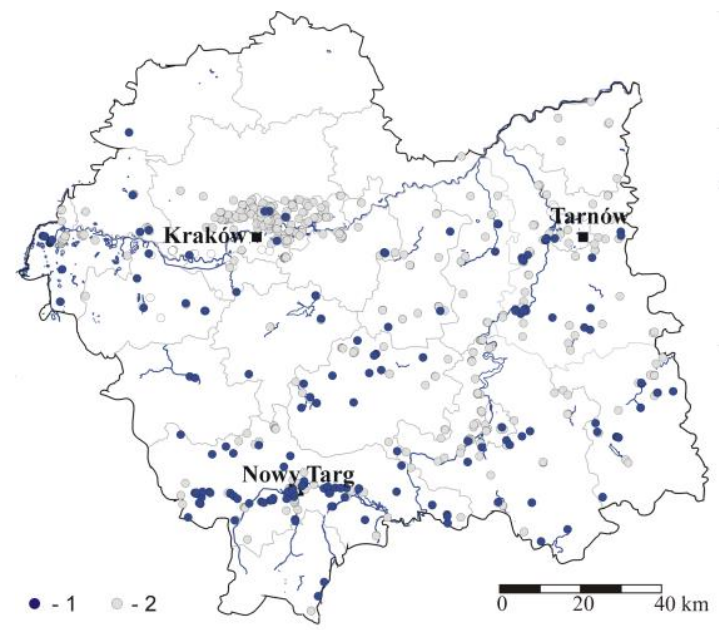

c)

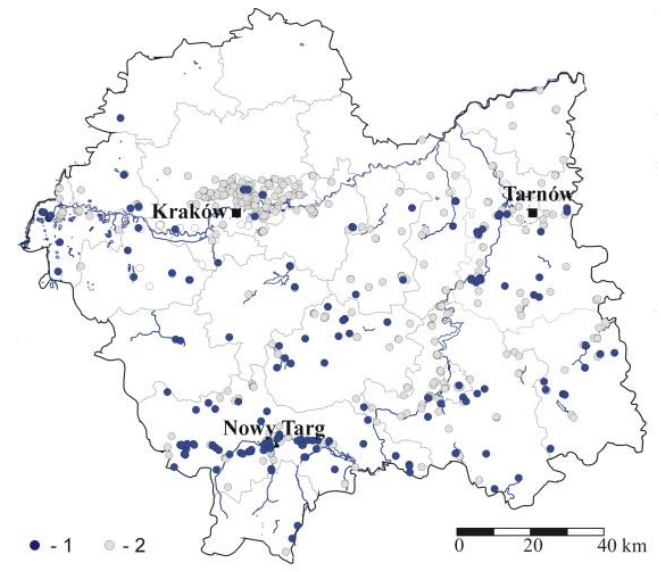

Fig. 1. Quaternary groundwater intakes in Małopolska (based on data from the Central

Hydrogeological Database, 2000-2013). Water quality in relation to the requirements indicated by:

a) Ochsner Ltd.; b) Viessmann GmbH; c) Dimplex Ltd. (1 - the manufacturer's requirements are met; 2 - limits are exceeded and an intermediate heat exchanger must be used). 
The overall depth of wells in Quaternary formations in the database analysed ranged up to a maximum of $71 \mathrm{~m}$. These wells are used to extract water from the depth (sampling depth) of up to $33 \mathrm{~m}$. The aquifer, which is a layer up to approximately $30 \mathrm{~m}$ thick and occurs at depths of up to $70 \mathrm{~m}$, consists mainly of sands and gravels with admixtures of pebbles, sands (clayey, with gravel, with pebbles and silty), tills, gravels (with pebbles, sandy) and other formations (rock debris, mud, dust, regolith, etc.).

Waters from Quaternary formations within the Małopolska Province exhibit highly variable physical and chemical parameters (Tab. 1, Fig. 1). In view of the requirements indicated by Viessmann and Dimplex, water from $27.57 \%$ of wells can be used directly in their installations assisted by a water/water heat pump; according to Ochsner's requirements, $30.96 \%$ of wells are suitable (Fig. 1). In the remaining cases $(69.04 \%$ of wells according to the requirements indicated by Ochsner and $72.43 \%$ of wells according to Viessmann's and Dimplex's requirements), water from Quaternary formations may be used in installations assisted by a water/water heat pump, but an intermediate heat exchanger has to be installed before the heat pump as a result of parameter limits being exceeded. Locations of wells that meet the requirements of individual producers are shown in Fig. 1. Cases where limits are exceeded for the parameters tested can be observed locally, especially in large urban areas, i.e. Kraków, Tarnów and Nowy Targ.

Thus the water analysed can be used in both single-well and double-well installations by any manufacturer, but in many cases an intermediate heat exchanger has to be used before the heat pump in order to ensure the long and safe operation of the entire system.

Surveys conducted annually by the Polish Organisation for the Development of Heat Pump Technology (PORT PC) (2016) indicate that out of the overall number of units sold in 2015 , only $0.4 \%$ were water/water installations (86 units) [20]. Such a low share of this type of heat pumps may be related to the still fairly high investment expenditure required (it may reach double the price of an installation that uses traditional energy carriers in many cases), complex legal regulations requirement for and the fact that possibilities of using underground water in such systems have not been researched so far [2,6]. The Geological and Mining Law [21] regulating principles of exploration, recognition and exploitation of groundwater, especially the development of a geological project as well as its submission to the aforementioned administration authority are obligatory. From the other hand, other procedures must comply with regulations of the Water Law [22]. The spent water, that is discharged into waters or to the ground is considered as wastewater, and its quality have to meet the requirements included in documents pertaining to the protection of natural environment. These installations can undoubtedly help to reduce the emission of harmful substances into the atmosphere [23] and thus contribute to improving air quality in the Małopolska region. Additionally, the use of heat pumps for district heating purposes is often mentioned (following the models set in other European countries) as an energyefficient solution for producing heat [24].

\section{Summary}

Groundwater used as the low-temperature heat source in systems assisted by heat pumps should, inter alia, meet the requirements related to its physical and chemical parameters indicated by installation manufacturers. This is the main issue related to ensuring the safe and proper operation of a groundwater-based system.

The assessment conducted demonstrates that in the Małopolska Province, groundwater from Quaternary formations could be used in low-temperature systems both in terms of potential water flow rates (several $\mathrm{m}^{3} / \mathrm{h}$ ) and water temperatures (from +6 to $+20^{\circ} \mathrm{C}$ ). Geological and hydrogeological conditions are favourable as well. Physical and chemical 
water parameters in some of the wells analysed do not meet the requirements indicated by heat pump manufacturers.

The fact that the manufacturers' requirements concerning physical and chemical indicators are not met does not preclude the use of such water resources in systems used for producing energy. A solution used in many installations are intermediate heat exchangers placed before the heat pump, which transfer the energy stored in groundwater to a medium whose parameters do not affect the service life of the installation.

The selection of a specific heating system assisted by a water/water heat pump should be based on an up-to-date analysis of the chemical composition of water, preferably conducted by an accredited testing laboratory. The analysis should cover all parameters indicated by the manufacturer of the heat pump in question as well as parameters that may affect corrosion or clogging processes; in this manner, a number of problems that may occur during the operation of the entire system can be avoided.

Despite the possibilities of using groundwater from shallow aquifers in low-temperature systems, such installations still have the smallest share in the heat pump market in Poland.

The authors would like to thank OCHSNER Wärmepumpen GmbH, Viessmann Sp. z o.o. and Dimplex Sp. z o.o. for providing technical materials for the purposes of this paper. This work has also been conducted under AGH-UST statutory research grants Nos. 11.11.140.797 and 11.11.140.321.

\section{References}

1. B. Sanner, GHC Bull. 22, 2, 19-25 (2001)

2. J. Mazurkiewicz, E. Kmiecik, B. Tomaszewska, Pol. Geol. Rev. 63, 10/2, 926-930 (2015)

3. K. Niedbalska, P. Bukowski, A. Haładus, SGEM 5, 1, 549-556 (2015)

4. K. Rafferty, GHC Bull. 22, 1, 16-24 (2001)

5. V. Pisarev, Design of a heat pump systems for heating (UR Rzeszow, 2013) (in Polish)

6. M. Forsen, Heat pumps-technology and environmental impact (SVEP, 2005)

7. M. Rubik, Heat pumps in low-temperature geothermal systems (Multicobooks, Warsaw, 2011) (in Polish)

8. Viessmann (http://www.viessmann-us.com/) (access 2017)

9. J. Mazurkiewicz, E. Kmiecik, B. Tomaszewska, Analysis of the possibility to use the quaternary groundwater in the low-temperature geothermal systems in Matopolska. Part II. Zawoja-3 Case Study, Pol. Geol. Rev. (to be published)

10. J. Mazurkiewicz, Evaluation of prospective areas for low-temperature geothermal water utilization in Malopolska Voivodship, Poland (PhD defense, to be published) (in Polish)

11. SCO, Area and population in the territorial profile in 2016 (Stat. Gov., Warszawa, 2016) (in Polish)

12. A.P. Barbacki, W. Bujakowski, L. Pajak, Atlas of geothermal water reservoirs in Malopolska (MEERI PAS, Krakow, 2006)

13. S. Satora, Infra. Eco 2, 61-70 (2007)

14. J. Mazurkiewicz, E. Kmiecik, B. Tomaszewska, Geol. Explor. Tech. Geoth. Energ. Sust. Dev. 2, 45-58 (2013)

15. W. Bujakowski, B. Tomaszewska, M. Miecznik, Renew. Energ. 99, 420-430 (2016) 
16. B. Tomaszewska, M. Rajca, E. Kmiecik, M. Bodzek, W. Bujakowski, K. Wątor, M. Tyszer, Desalin. 406, 74-82 (2017)

17. S. Pergól, J. Sokołowski, Balance of exploitation resources of underground waters of Poland, as of December 31, 2016 (PGI-NRI, Warsaw, 2016) (in Polish)

18. R. Bereś, G. Cieśla, L. Czarnecka, B. Dębska, K. Dulemba, M. Dzierko, E. Gondek, A. Główka, K. Gołębiowska, M. Janik, D. Kapustka, R. Listwan, D. Łęczycka, M. Ogar, B. Pająk, T. Reczek, K. Synowiec, E. Żelazowski, D. Żmuda, State of the Environment Reports in Malopolska 2002 (GIOS, Warsaw, 2003) (in Polish)

19. S. Satora, Influence of geological environment on design of drilled wells and hydrogeological regime of tapped underground waters (UR Krakow, Krakow, 2008)

20. POHPTD (www.portpc.pl) (access 2017)

21. Geological and Mining Law (Journal of Laws 2016 item 1131)

22. Water Law (Journal of Laws 2015 item 469)

23. D. Borge-Diez, A. Colmenar-Santos, C. Perez-Molina, A. Lopez-Rey, Energ. 36, 8, 5027-5036 (2015)

24. R. Lund, U. Persson, Energ. 110, 1, 129-138 (2016) 